\title{
Equation Chapter 1 Section 1 Corn Suitability Rating for Southern Highland Zone of Tanzania - A Feasibility Assessment at the TARI-Uyole, Mbeya, Tanzania
}

\author{
Johnson Godlove Mtama ${ }^{1, ~ *}$, Charles Lee Burras ${ }^{2}$, Balthazar Michael Msanya ${ }^{3}$ \\ ${ }^{1}$ Tanzania Agricultural Research Institute, Department of Natural Resources, Mbeya, Tanzania \\ ${ }^{2}$ Department of Agronomy, Iowa State University, Ames, USA \\ ${ }^{3}$ Sokoine University of Agriculture, College of Agriculture, Department of Soil and Geological Sciences, Morogoro, Tanzania \\ Email address: \\ johnsonmtama@gmail.com (J. G. Mtama) \\ ${ }^{*}$ Corresponding author
}

\section{To cite this article:}

Johnson Godlove Mtama, Charles Lee Burras, Balthazar Michael Msanya. Equation Chapter 1 Section 1 Corn Suitability Rating for Southern Highland Zone of Tanzania - A Feasibility Assessment at the TARI-Uyole, Mbeya, Tanzania. American Journal of Agriculture and Forestry. Vol. 8, No. 3, 2020, pp. 64-68. doi: 10.11648/j.ajaf.20200803.12

Received: November 25, 2019; Accepted: December 23, 2019; Published: June 4, 2020

\begin{abstract}
Corn productivity indices (CSR2T) for representative soils in the Southern Highland Zone of Tanzania were developed. The approaches used were derived from Iowa State University's CSR2. Consistent with ISU, index points were applied to the pedon based on the USDA Soil Taxonomy subgroup, family particle size class, and available water holding capacity, solum depth and resilience to degradation characterizations. Additional index points were applied based on field conditions especially slope, erosion history and flooding or ponding risk in order to determine the inherent productivity potential of the soils in the work sites. The results were used to develop the Corn Suitability Rating in Tanzania (CSR2T) for the soil settings of Southern Highlands. Sites' characterization results were linked with the maize field experimental results from 2003 to 2016 to determine the inherent corn productivity indices for the sites. The soils were found to have CSR2T values of 72, 56, 62 and 48 for Uyole, Mbimba, Inyala and Seatondale farms, respectively. The soils of Seatondale were observed to be more limited by water holding capacity. However, generally the study soils are observed to have good pedogenic potential for corn productivity and very minimal pedogenic limitations for corn productivity. The most serious limitation seems to be low water holding capacity.
\end{abstract}

Keywords: Corn, Suitability, Taxonomy, Pedon

\section{Introduction}

Corn suitability is a technology aimed at quantifying soil's potential for corn yield production. The idea of corn suitability can be traced back to 1930's. In Nebraska, the first study is reported to be done in 1949 [1]. The Nebraska's crop ratings were organized to fit the Nebraska's soil maps. This work was updated by the Nebraska's virtual corn productivity rating [1]. In Canada, the crop productivity rating is reported to be a function of soil properties and field condition [3]. In California, the storie index had been used over 50 years; it was highly popular and important. It was hand calculated by soil survey staff and collaborators with each new soil survey. It used the multiplicative approach to elaborate soil productivity to crop production as a product of soil depth and texture, permeability, soil chemistry, drainage and runoff, and climate [4]. As a result, it was highly subjective with different soil scientists determining different values, difficult to apply across the entire state and would not integrate with modern data and web-based soil maps. As a result, they developed this revised storie index, which is explained in their paper. A revised version was produced to fit the digital soil information use [5, 6]. In Iowa, land productivity estimation can be traced back to 1947. Soil survey information became a useful tool for land tax assessment [7, 8]. Based on the soil survey information available up to 1960 s, corn productivity rating was developed. Where the land was rated for its crop yield production potential [9-11]. 
The move towards efficient and precise agricultural production necessitated the development of the corn suitability rating. As an agricultural production planning tool, it has resulted in significantly increased agricultural turnover in terms of income for both farmers and state [12]. CSR2 was recently developed [12] to fit the updated and dynamic soil information availed by USDA NRCS Web Soil Survey (see: http://websoilsurvey.sc.egov.usda.gov/) that was not available when CSR was developed. It originated from the CSR but it uses an algorithm whose parameterization is based on current soil survey information and easily accessed Soil Web Survey. Properties like taxonomic classification, family particle size, field conditions, and expert judgment are used to determine the yield potential for a given soil-mapping unit [12-14]. The rationale for CRS2 is the dynamic change in soil properties that happened after the CRS development, some updated soil survey information could not be contained in CRS $[12,14$, 15]. CSR2, like CSR, assumes standard agronomic practices including improved corn varieties, optimal nutrient levels, proper plant populations, controlled soil erosion, adequate soil drainage and appropriate rainfall through the growing season $[11,13,16]$

The objective of this paper is to establish the corn suitability rating for the representative soil of Southern Highland Zone of Tanzania (CSR2T).

Hypothesis for Soil's Corn Productivity Potential of the SHZT

Ho: The corn productivity in the Southern Highland Zone is readily predictable using the corn suitability equation (CSR2T)

$\mathrm{Ha}_{1}$ : Corn productivity in Southern Highland Zone is not readily predicted based on the corn suitability equation (CSR2T) because the equation's factors are correlated to each other (i.e., they lack statistical independence).

$\mathrm{Ha}_{2}$ : Corn productivity in Southern Highland Zone is not readily predicted based on the corn suitability equation (CSR2T) because the equation's factors are not the principal controllers for the region.

These hypotheses were tested using interaction of soil characterization and corn yields for four research stations in the Southern Highland Zone namely, Uyole, Mbimba, Inyala and Seatondale.

\section{Materials and Methods}

\subsection{Study Area}

Corn yields were retrieved from TARI-Uyole maize field experimental results in Southern Highland Zone. Three specific administrative units include Mbozi, Mbeya districts and Iringa Municipal. The working research sites involved Mbimba, Uyole, Inyala and Seatondale. Sites and profile description were done to determine the information on factors that influence corn suitability; the factors include soil classification, soil family particle size, field conditions, soil depth and soil water holding capacity characteristic (Table 3). Geological information of the working sites was retrieved from the geological maps. The corn yields were retrieved from the TARI Uyole library from the Annual Internal Research meeting reports. The variety used for the study is Uyole hybrid 6303 (UH 6303). The corn yields obtained ranged in timeframe of 2003 to 2016.

\subsection{Determination of the Factors for Corn Suitability}

Using USDA soil taxonomic classification, the soil samples were collected across the pedons in the four working sites: Mbimba, Uyole, Inyala and Seatondale. Eventually laboratory work was conducted at Sokoine University of Agriculture for determination of diagnostic horizon parameters to facilitate the classification process of the soils. The field site's and Pedons' descriptions were also used to assist the classification of the soils. Field conditions, slope phase of the sites were determined using the clinometer. The data obtained from the clinometer reading were rated using the guidelines to determine the slope phase of the sites. Erosion phase was determined using the guideline that links the slope percent and the erosion phase. Available water holding capacity of the soil, undisturbed core sampling was conducted at each pedon in three depths namely $0-5 \mathrm{~cm}, 45-$ $50 \mathrm{~cm}$ and $95-100 \mathrm{~cm}$. The samples were submitted to TARI Mlingano, national soil laboratory for determination of soil water characterization. Sola depths were established using the opened pedons. The depth of each pedon was recorded using the measuring tape.

\subsection{Corn suitability Rating for the Soils of Tanzania (CSR2T)}

Corn suitability for soils of Southern Highlands of Tanzania can be determined using the equation with independent variables like taxonomic subgroup, family particle size, field conditions, soil water holding capacity and soil depth in relation to tolerable soil erosion, assuming climate, genetics and management are kept constant. These factors were symbolized S, M, F, W, and D, respectively. The soil taxonomic subgroups classes were designated values between 5 and 100; with the 100 value, soil representing the best soil for corn productivity and vice versa. The reduction of points from soils rated value in the equation depends on existing corn yield limiting factors like slope, erosion and sedimentation, channels, flooding, paleosol and ponding [8].

\section{$\mathrm{CSR} 2 \mathrm{~T}=\mathrm{S}-\mathrm{M}-\mathrm{F}-\mathrm{W}-\mathrm{D}$}

Where:

$\mathrm{S}=$ Soils taxonomic subgroup classification,

$\mathrm{M}=$ Family particle size class,

$\mathrm{F}=$ Field conditions of a particular site,

$\mathrm{W}=$ Available water holding capacity of soil,

$\mathrm{D}=$ Soil depth factor associated with tolerable soil erosion.

Previous maize yield, soil properties and field condition data from TARI Uyole experiments were used to suggest the CSR2T of the soil mapping units. 


\section{Results and Discussion}

\subsection{Results}

The four field sites represent important corn producing soils classification for the respective regions of SHZT. The detailed results on the suitability rating are shown in (Tables 1,2 and 3 ). The results indicate the practical success in the corn suitability rating for the representative soil of SHZT.

Table 1. Classification of the representative soils of SHZT.

\begin{tabular}{ll}
\hline Pedon Id & Soil classification \\
\hline Seatondale & Fine, illitic, active, isothermic Typic Hapludult \\
Mbimba & Fine, illitic, active, isothermic, Andic Paleudalf \\
Inyala & Fine, illitic, active, isothermic, Mollic Paleudalf \\
Uyole & Pumiceous, mixed, superactive, isothermic, Typic Hapludand \\
\hline
\end{tabular}

Table 2. CSR2T function variables 'points impact in rating the representative soils of SHZT.

\begin{tabular}{llllll}
\hline Pedon Id & S-factor & M-factor & F-factor & W-factor & D-factor \\
\hline Seatondale & 86 & 4 & 10 & 24 & 0 \\
Mbimba & 89 & 4 & 5 & 24 & 0 \\
Inyala & 90 & 4 & 0 & 24 & 58 \\
Uyole & 100 & 4 & 0 & 24 & 0 \\
\hline
\end{tabular}

$\mathrm{S}=$ Soils Taxonomic Subgroup, M=Family particle size classification, F=field condition of a particular size, W=Water holding capacity of the soils, $\mathrm{D}=$ Tolerable erosion, $\mathrm{CSR} 2 \mathrm{~T}=$ corn suitability rating for Tanzania.

Table 3. Inherent soil properties of the representative pedons in SHZT.

\begin{tabular}{lllllll}
\hline \multirow{2}{*}{ Pedon Id } & \multirow{2}{*}{ Subgroup } & $\begin{array}{l}\text { Water holding } \\
\text { capacity }(\mathbf{m m} / \mathbf{m})\end{array}$ & Family particle size & Solum depth $(\mathbf{c m})$ & & Field conditions \\
\cline { 6 - 7 } & & 60 & Pumiceous & $130+$ & Slope phase & Erosion phase \\
\hline Uyole & Typic Hapludand & 60 & Fine & $117+$ & $\mathrm{B}$ & $\mathrm{O}$ \\
Mbimba & Andic Paleudalf & 56 & Fine & $120+$ & $\mathrm{A}$ & 1 \\
Inyala & Mollic Paleudalf & 41 & Fine & $80+$ & $\mathrm{C}$ & $\mathrm{O}$ \\
Seatondale & Typic Hapludult & 33 & &
\end{tabular}

Slope phase: $\mathrm{A}=0-2 \% ; \mathrm{B}=2-5 \%$; $\mathrm{C}=5-9 \%$. Erosion phase: $0=$ no evident erosion, $1=$ none to slightly eroded, no evidence of exposed $\mathrm{B}$ horizon when ploughed 18 to $30 \mathrm{~cm}$ or more of A horizon. $2=$ moderately eroded, usually 8 to $18 \mathrm{~cm}$ of total A horizon.

Table 4. Corn yield (t/ha) records from the experimental sites of representative sites of SHZT.

\begin{tabular}{lllll}
\hline Year & Uyole & Seatondale & Mbimba & Inyala \\
\hline 2003 & 6.74 & & 5.81 & \\
2004 & 5.83 & & 4.73 & 6.92 \\
2005 & 9.72 & 6.14 & 5.11 & \\
2010 & 5.98 & 5.8 & & 11.79 \\
2012 & & 6.60 & 8.30 & \\
2013 & 7.10 & 7.11 & 7.7 & 7.5 \\
2014 & 8.96 & 5.3 & & \\
2016 & 7.8 & 7.7 & & \\
\hline
\end{tabular}

The yield records retrieved from annual research reports at TARI Uyole.

\subsection{Discussion}

The representative soil of SHZT can be classified as Ultisols, Alfisols and Andisols (Table 1). For these soils, available water holding capacity, soil taxonomic subgroup, field condition, and family particle size class seem to limit their productivity. However, the AWHC affects the most (Table 2). Corn Suitability Rating 2 values for Tanzania; 72, 62, 56 and 48 for Uyole, Inyala, Mbimba and Seatondale respectively indicate the inherent productivity of soils Southern highlands of Tanzania [17]. The same findings were observed [7, 4] in their work on revised storie index for use with digital soil information. In addition to that [12] also found that the corn suitability rating is affected by inherent soil properties such as soil water holding capacity, soil taxonomic subgroup, field conditions and family particle size [18]. The soils of Uyole were observed to have less inherent soil limitations to corn productivity (Tables 3 and 4) while soils of Seatondale were observed to have more inherent limitation to corn productivity; soil depth, slope and water holding capacity highly affected corn productivity in the area [18-21]. Despite of these observed limitations; generally the soils of SHZT can be categorized as suitable for corn production, and the investment on irrigational farming would maximize the potential productivity of the zone in corn production [22-24]. Soil erosion is identified as one of the threats in undulating agricultural farming systems in SubSaharan Africa [25]. Appropriate management options are needed to enhance the productivity of these soils including terracing farming systems in areas whose slope phase fall in 
category C. Corn suitability rating is useful tool in determining the value of land in agricultural investments especially in deciding the land rent value and estimating the state's revenue [7, 26-28]. The properties of agroecologies of farming system have direct contribution to the corn suitability rating of the respective agroecology [29, 30].

\section{Conclusions and Recommendations}

\subsection{Conclusions}

The representative soil samples from Southern Highland Zone of Tanzania have provided the empirical evidence that corn suitability rating depends heavily on inherent soil limitations for corn productivity. In that case, the study rejects the alternative hypothesis, and supports the null hypothesis that the corn productivity in the Southern Highland Zone is readily predictable using the corn suitability equation. However, the soils of Uyole demonstrated the high productivity potential followed by Inyala, Mbimba and lastly Seatondale. Soil water holding capacity, textural class and field conditions are the soil properties observed to limit the corn productivity potential of the study soils in the Southern Highland Zone of Tanzania. The sola depths were observed to be optimal for supporting corn productivity in all the study pedons. The great soil landscape relationships highly influence the soil productivity indices. Seatondale site is a relatively high slope landscape soil; the observed corn suitability is lower than the other sites.

\subsection{Recommendations}

Extensive study to cover more soil mapping units representing the SHZ is required to obtain better statistical power for the Southern Highland Zone soil survey and corn suitability rating results. The soils of Seatondale require more management attention to improve nutrient status and water holding capacity, an initiative to promote the Tanzania's Corn Belt productivity.

\section{Acknowledgements}

The authors greatly acknowledge the assistance received from USAID through iAGRI project for financing this research work, without their support this work would not be achieved.

\section{References}

[1] H. G. Halcrow, and H. R. Stucky. "Procedure for land reclassification in Montana". Montana Agriculture Experiment Station Bulletin 459: 39, 1949.

[2] B. B. Johnson and T. Rosener. "Nebraska's virtual corn suitability rating". Cornhusker Economics. Paper 455. Univ. Nebraska, Lincoln. 2010.

[3] J. Mitchell. "Productivity ratings and their importance in the soil survey report". Transactions of the 4th International Congress of Soil Science 1: 356-360, 1950.
[4] R. E Storie. "An index for rating the agricultural values of soils". Bulletin 556, California Agricultural Experiment Station, Berkeley, CA. 1932.

[5] R. H. Rust, and L. D. Hanson. "Crop equivalent rating guide for soils of Minnesota". University of Minnesota Agriculture Experiment Station Miscellaneous Report 32-1975. 1975.

[6] O'Green, A. T., S. B. Southard, and R. J. Southard. "A revised Storie Index for use with digital soils information". University of California Agricultural and Natural Resources Publication 8335: 2-11. Oakland, CA. 2008.

[7] W. H. Scholtes and F. F. Riecken. "Use of soil survey information for tax assessment in Taylor County, Iowa". Soil Science Society Proceedings 16: 270-273. 1952.

[8] R. E. Storie. "Storie index soil rating". Oakland: University of California Division of Agricultural Sciences Special Publication 3203. 1978.

[9] T. E. Fenton, E. R. Duncan, W. D. Shrader, and L. C. Dumenil "Productivity levels of some Iowa soils". Special Report No. 66. Iowa Agriculture Experiment Station, Ames, 1971.

[10] J. K. Ableiter, "Productivity ratings in the soil survey report," Soil Science Society of America Journal, vol. 2: 415-422, 1938.

[11] K. P. Woli, C. L. Burras, L. J. Abendroth, and R. W. Elmore. "Optimizing corn seeding rates using a field's corn suitability rating”. Agronomy Journal 106: 1523-1532. 2014.

[12] C. L. Burras, G. A. Miller, T. E. Fenton, and A. M. Sassman. "Corn suitability rating 2 (CSR2) equation and component values," http://www.extension.iastate.edu/soils/suitabilitiesinterpretations, 2015 (retrieved June 18, 2015).

[13] S. Butzen. "Best management practices for corn after corn," Crop Insights 22 (6): 1-5, 2003.

[14] E. M. Craft, R. M. Cruse, and G. A Miller, "Soil erosion effects on corn yields assessed by potential yield index model", Soil Science Society of America Journal 56: 878-883, 1992.

[15] R. Lal. "Global soil erosion by water and carbon dynamics". In R. Lal, J. Kimble, E. Levine and B. A. Stewart (Eds.) Soils and Global Change. Advances in Soil Science, CRC Press, Baco Raton, FL. 1995.

[16] G. Cucci, G. Lacolla, M. Pagliai, and N. Vignozzi, "Effect of reclamation on the structure of silty-clay soils irrigated with saline-sodic waters", International Agrophysics 29: 23-30, 2015.

[17] M. Stinn, and M. Duffy. "What is the Precision of Land Survey Values? " Choices - The Magazine of Food, Farm and Resources Issues 27 (3): 1-4. 1999.

[18] M. Duffy. "Value of soil erosion to the land owner". Agr Decision Maker, File A1-75 Iowa State University, Department of Economics Extension and Outreach. Available at: https://www.extension.iastate.edu/agdm/crops/html/a175.html, 2012 (retrieved November 27, 2015).

[19] L. D. Hopkins. "Methods for generating land suitability maps: a comparative evaluation". American Institute of Planners 43: 386-400, 1977.

[20] L. D. Hopkins. "Land suitability analysis: Methods and interpretation". Landscape Research 5: 8-9, 1979. 
[21] S. K. Singh, V. Hoyos-Villegas, J. H. Houx, and F. B. Fritschi. "Influence of artificially restricted rooting depth on soybean yield and seed quality". Agricultural Water Management 105: 38-47. 2012.

[22] R. Lal. "Erosion-crop productivity relationships for soils of Africa". Soil Science Society of America Journal 59: 661-667, 1995.

[23] E. P. Ukaegbu, and C. L. A. Asadu. "Suitability rating of soils of Owerri agricultural zone, Nigeria, for rainfed monocropping of maize". Journal of Agricultural, Biotechnology and Ecology 5: 55-66. 2012.

[24] D. Pimentel. "Soil erosion: A food and environmental threat". Environment, Development and Sustainability 8: 119-137. 2006.

[25] J. A. Phillips. "Use of soil surveys in land valuation for tax assessment". Iowa State University. Iowa State Digital Repository Retrospective Theses and Dissertations. Paper 3259 (Available

at: http://lib.dr.iastate.edu/cgi/viewcontent.cgi?article $=4258 \&$ cont ext=rtd,reviewed November 27, 2015). 1968.
[26] M. A. Haddad, P. F. Anderson, S. Thol, C. Hertel, and B. Schmidt. "Assessing the future of the bioeconomy in Greene county Iowa". Rural and Community Development 4: 15-33, 2009.

[27] N. Tremblay, Y. M. Bouroubi, C. Bélec, R. W. Mullen, N. R. Kitchen, W. E. Thomason, and I. Ortiz-Monasterio. "Corn response to nitrogen is influenced by soil texture and weather". Agronomy Journal 104: 1658-1671. 2012.

[28] B., A Sánchez. Rasmussen, and J. R. Porter. "Temperatures and the growth and development of maize and rice: a review". Global Change Biology 20: 408-417. 2014.

[29] M. J. T Norman, C. J. Pearson, and P. G. E. Searle. "The ecology of tropical food crops". Cambridge University Press, Cambridge. pp. 369. 1984.

[30] A. M Sassman, G. A. Miller, and C. L. Burras. "Iowa Soil Properties and Interpretations Database (ISPAID) 8.1". Iowa State University Soils and Land Use (http://www.extension.iastate.edu/soils/ispaid) Reviewed June 17, 2015. 